\title{
Economic valuation of ecosystem services in protected areas: A case study from Nepal
}

\begin{abstract}
B. KC ${ }^{1}$, P. N. Kandel ${ }^{2}$ and S. Adhikari ${ }^{3}$
The research examines the value of ecosystem services in Baghmara Buffer Zone Community Forest of Nepal determining willingness of local users and tourists for sustainable management and conservation of natural resources as well as recreational and aesthetic services, during September of 2010. The contingent valuation survey was administered to 95 users and 100 tourists. For users, the distance to forest, family size, nature of residence, gender and size of land holding seem to be the prominent factors that affected upon their willingness to pay. The projected average willingness to pay by all users for recreational and aesthetic services was NRs. 33,347 (about US\$ 460) per year. The tourists were divided into domestic and international to elicit willingness to pay for ecosystem services. The responses were found varied according to the nature of tourists. For domestic tourists, income was only factor that affected their willingness to pay, but for international tourists along with income, gender, travel group and education were major determinants of willingness to pay. The average projected willingness to pay by all tourists was US\$3,806,468 per year.The research highlights that the conservation area systems in Nepal has a high potential to generate additional resources against ecosystem services provided additional services to the tourists and a mechanism to tap such contribution.
\end{abstract}

\section{Key words: Ecosystem services, payment for ecosystem services, willingness to pay, Nepal}

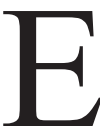
cosystem provides a wide range of goods and services to human-being which range from the relatively simple, such as reliable flow of clean water to complex such as carbon sequestration. Ultimately the human life depends on ecosystem services (ES) for fundamental necessities such as clean air, clean water and food production. Thus, ES are the provision of natural resources and healthy ecological systems that produce environmentally and economically valuable goods and services (Warner, 2008). According to Millennium Ecosystem Assessment (MEA, 2005), the ES are 'the benefits that people obtain from ecosystems'. The MEA further classifies them into provisioning, regulating, supporting and cultural services.

The benefits that the human-beings are receiving depend on the flow of ES and are non-existence, if these services stop to flow (Maskey, 2008). At present, however, many of these services provided by ecosystem are either undervalued or have no financial value due to lack of economic valuation practices at all. According to

Costanza et al. (1997), the ES are worth many trillions of dollars annually, yet most of these benefits carry no price-tag that could help alert societies to change in their supply or deterioration of the ecosystems that generate them. The missing market for ES adds to the problem, because most of the vulnerable segments of society, primarily in developing countries, depend upon those services directly or indirectly for their livelihoods. Therefore, any decision proves to be inefficient and infeasible from a social perspective, causing problems for sustainability and human well-being (Costanza et al., 1997). The MEA, 2005 reported that 60 to $70 \%$ of the ecosystem services are deteriorating faster than they can recover such as the forest provides bundles of ES, and there exists a different level of beneficiaries of these services. These unique features of most of the services, although acknowledged by people, are unaccounted, un-priced and, therefore, remain outside the domain of the market (Kumar, 2005). Hence, quantification and monitoring the flows of ES is important for their valuation.

1 Hariyo Ban Programme, CARE Nepal, E-mail: bhawanakc@gmail.com

2 FRA Nepal Project, Babarmahal, Kathmandu

3 CSUWN, Babarmahal, Kathmandu 
Protected Areas (PAs) are commonly established to conserve biodiversity, protect ecosystems and maintain ecological processes; many PAs are also expected to contribute to sustainable development and poverty reduction (Neto, 2003; Scherl et al., 2004; Rogerson, 2006). Numerous PAs throughout the world, however, are not financially self-sufficient; as a result, they are unable to meet either conservation or development objectives (IUCN, 2005). A number of potential mechanisms have been identified for enhancing the financial sustainability of PAs in which one of them could be the PES (Emerton et al., 2006) and also a tool to academics, policy makers and programme implementers to bring win-win approach for reducing poverty and ecosystem degradation (Pattanayak et al., 2010). Payments for Ecosystem Services (PES) have become a vital mechanism to translate external, non-market values of the environment into real financial incentives for the local actors to provide ecosystem services (Engel et al., 2008). The concept of PES relies on the assumption that assigning economic value to ecosystem services and exchanging them under a market system can produce efficient environmental outcomes (Engel et al., 2008; Pagiola et al., 2002; Wunder, 2005). The Quebec declaration has emphasized that ecotourism can be a valuable means for promoting the socio-economic development of host communities while generating resources for the preservation of natural and cultural assets. Further, it helps to protect the ecologically fragile areas, and even rehabilitate natural capital with the financial returns of ecotourism activities and, thus, contribute to the preservation of biological diversity and ecological balance (Collins, 1999; Gossling, 1999; Neto, 2003). Furthermore, various attempts were made in national and international regimes to gather the support for biodiversity conservation. Community based PES is a logical approach to ensure service provision and incentive to local mangers and to contribute to address both development objective and build management capacity at communitylevel, where communities have control over the quality or quantity of environmental services (Sommerville et al., 2010). From the PES, especially in developing countries, the poor households (HHs) and communities have very much potential to gain benefit as they have control on environmental services (Milder et al., 2010). Similarly, this mechanism also seems to have greater scope in developing countries like
Nepal where the state's fund is inadequate and the poverty and conservation issues are to be addressed together (Karna, 2008). But, due to lack of economic valuation of ecosystem services, it is very difficult to establish a benefit sharing mechanism.

PAs have to generate their own fund for sustainable conservation and development in the developing countries like Nepal. So, tourism can be a source with the potentiality of balancing both conservation and development. In Nepal, meager research has been carried out on tourism. Therefore, there is a gap to explore the opportunities of tourism instead of being playing inevitable role in the livelihoods of the local communities of the nation. Similarly, the valuation of ecosystem services is least studied and not in practice. Thus, for the sustainable and rational use of biodiversity and sustainable development, for creation of awareness, and to provide compensation to environmental service provider, further research, analysis and field practice must be conducted to explore the economic value of ecosystem services. In this regard, this article tries to explore the economic valuation of the ecosystem services in Baghmara Buffer Zone Community Forest (BBZCF) through determining Willingness to Pay (WTP) for sustainable management and conservation of natural resources and recreational and aesthetic services by users and tourists respectively.

\section{Materials and methods}

\section{Study area}

This study was conducted in Baghmara Buffer Zone Community Forest of Chitwan National Park (CNP) in September 2010. It lies in Bachhauli Village Development Committee (VDC) of Chitwan District, Nepal. It is located in subtropical region of lowland of Nepal between $27^{\circ} 14^{\prime} \mathrm{N}$ to $27^{\circ} 42^{\prime} \mathrm{N}$ latitudes and $83^{\circ} 50^{\prime} \mathrm{E}$ to $84^{\circ} 45^{\prime}$ E longitudes. The climate of study area is sub-tropical monsoon type with relatively high humidity at an elevation of 200 to $250 \mathrm{~m}$ above sea level. Monsoon rain prevails from late June to September and amount of annual rainfall ranges from $14.04 \mathrm{~mm}$ to $602.2 \mathrm{~mm}$ (Tamrakar, 2002). Heavy flooding occurs during monsoon. The average daily maximum temperature of the area in hot summer days is about $36.8^{\circ} \mathrm{C}$. Spring starts from March and is immediately followed by summer and that ends in June (Pant, 2003). 
The maximum temperature is about $7.8^{\circ} \mathrm{C}$ in cool dry winter season which occurs from October to February. The buffer zone of CNP was handed as BBZCF in 15 June, 1995. The users of BBZCF are disbursed in 4 wards namely Badhrani, Malpur, Padaria and Sauraha. The BBZCF was selected to conduct this study due to the following reasons: i) critical to prove the relationship between ES and the users/tourists; ii) rich in biodiversity in spite of having small area; and iii) accessibility. Out of the total area, 133 ha is covered with forest, 67 ha grassland, and the rest 15 ha wetland (BBZCF Operational Plan, 2003-2007). This is a secondary riverian forest rich in biodiversity with certainty of viewing one-horned Asian rhinos, varieties of deer and beautiful birds. In addition to this, its relatively easy access makes it one of the popular destinations visiting the CNP (Singh and Sharma, 2008). Though it claims to be a small area, it is a good combination of grazing land, wetland and mixture of bushes and trees for hiding places providing an excellent habitat for wildlife (Singh and Sharma, 2008). As a result, it has reduced the pressure of tourists in the CNP, and extended habitat for wildlife outside the National Park.

The research followed a mixed-method approach which was based on pragmatism paradigms which enhances the validity of the research findings by using complementary qualitative and quantitative methods, and enabling triangulation of data from the two methods (Johnson et al., 2007; McMurray et al., 2004; Tashakkori and Teddle, 2003). The approach also bridged the gap between the scales of social realities, as qualitative methods often explore behavioral aspects of social life at a micro-level, while quantitative methods enabled investigation of social perspectives at a macrolevel (Bryman, 2006).

\section{Contingent valuation}

This study applied Contingent Valuation Method (CVM), a form of "Stated Preference Method" to identify these: i) willingness to pay and ii) quantify and convert services into the monitory value. The Contingent Valuation $(\mathrm{CV})$ is a standardized and widely used survey method for estimating WTP or Willingness to Accept (WTA) compensation for use, existence and bequest values for resources (Loomis, 1996). The fact that CVM is based on asking what people say they would do (stated) as opposed to what people are observed to do (revealed) is the source of its greatest strength as well as its greatest weakness (IIED, 2003).

A two-fold survey was conducted; one with the users and another with the visitors. Detail information on independent variables for user and tourists are presented in table 1 and 2 respectively. During the survey, a bid amounts were posed to both the users and the visitors to elicit the WTP. As part of quantitative method, questionnaire survey was administered to 100 tourists (returned rate $70 \%$ ) and 95 local user group members. The visitors used self administered process to fill the questionnaire, and returned to the researcher while a face to face survey was conducted to administer the questionnaire for the local users. The survey was conducted with the users to know WTP for the sustainable use and management of BBZCF as their conservation efforts with factors affecting their WTP while the visitors to know their WTP for the recreational and aesthetic services and factors affecting their WTP. Likewise, 4 events of focused group discussions (FGD) were conducted as part of qualitative and in-depth group interview.

\section{Sampling}

The local people of four wards namely Badhrani, Sauraha, Malpur and Padaria were concerned with BBZCF. So, the total users were stratified into four wards. A number of local user groups were selected according to the weightage of population in each ward (i.e. Wards with large-size contained large number of HHs and vice versa). Out of the total HHs within each ward, $10 \%$ were selected randomly from each ward stratum. Thus, Stratified random sampling was applied to select interviewees among the local users. In case of tourists, respondents were purposively selected those who visited BBZCF.

\section{Multiple linear regression model}

The following multiple linear regression model was developed to find out the relationship between the WTP and the factors affecting the WTP for both the users and the visitors (Baral et al., 2008; Khanal et al., 2010).

$$
\begin{aligned}
\mathrm{WTP}= & \beta_{0}+\beta_{1} \mathrm{X}_{1}+\beta_{2} \mathrm{X}_{2}+\beta_{3} \mathrm{X}_{3}+\ldots \ldots \ldots \ldots \ldots+\beta_{\mathrm{n}} \mathrm{X}_{\mathrm{n}} \\
& + \text { error, }
\end{aligned}
$$

where, WTP is willingness to pay by the visitors for the experience they had from the aesthetic and recreational services of the BBZCF and by 
the users for the sustainable management and conservation of the BBZCF (dependent variable); $\beta_{0}$ to $\beta_{\mathrm{n}}$ are parameters to be estimated; and $\mathrm{X}_{1}$ to $\mathrm{X}_{\mathrm{n}}$ are explanatory variables influencing WTP.

For users, Probability (WTP) $=\beta_{0}+\beta_{1}$ distance + $\beta_{2}$ family size $+\beta_{3}$ gender $+\beta_{4}$ landholding $+\beta_{5}$ occupation $+\beta_{6}$ residence + error

For visitors, Probability (WTP) $=\beta_{0}+\beta_{1}$ gender $+\beta_{2}$ age $+\beta_{3}$ education $+\beta_{4}$ environmental membership $+\beta_{5}$ income $+\beta_{6}$ guide residence + $\beta_{7}$ travel size $+\beta_{8}$ travel group + error
$50 \%$ in the range of NRs. 5.08 - NRs. 50.14 (US\$ $0.07-0.69)$ per $\mathrm{HH}$ per month, $13 \%$ were in range of NRs. 43.3 - NRs. 100.28 per HH per month (US\$ $0.69-1.38$ ) and remaining $21 \%$ were willing to pay more than NRs. 100.28 (US\$ 1.38)per HH per month. The mean WTP was NRs. 2.91 (US\$ 0.04) per HH per month. According to the records of the BBZCF, the total number of HHs was 956. Therefore, the projected average WTP by all the users would be NRs. 2778.9 (US\$ 38.24) per HH per month and NRs. 33346.81 (US\$ 458.88) per HH per year.

Table 1: Definition and description of the independent variables for users

\begin{tabular}{llc}
\hline Independent variable & \multicolumn{1}{c}{ Description } & Variable type \\
\hline $\begin{array}{l}\text { Distance } \\
\text { Family size }\end{array}$ & $\begin{array}{l}\text { HHs distance from the BBZCF (in meter }) \\
\text { Number of member in HHs } \\
\text { Gender }\end{array}$ & $\begin{array}{c}\text { Continuous } \\
\text { Continuous }\end{array}$ \\
Land holding & $\begin{array}{l}\text { Land holding size owned by a HH (Katha) } \\
(1 \text { katha }=0.007 \text { Hectare })\end{array}$ & Binary \\
Coccupation & $\begin{array}{l}\text { Main income source of HH }(0=\text { agriculture } \\
\text { and } 1=\text { other than agriculture })\end{array}$ & Binary \\
Residence & Permanent residence $(0=$ yes and $1=\mathrm{No})$ & Binary \\
\hline
\end{tabular}

Table 2: Definition and description of the independent variables used for tourists

\begin{tabular}{|c|c|c|}
\hline Variable name & Description & Variable type \\
\hline Gender & Respondent sex $(0=$ male and $1=$ female $)$ & Binary \\
\hline Age & $\begin{array}{l}\text { Respondent age in years (below } 25=0 \text { and } \\
\text { others }=1 \text { ) }\end{array}$ & Ordered \\
\hline Education & $\begin{array}{l}\text { Education level }(0=\text { high school and } 1=\text { others } \\
\text { than high school) }\end{array}$ & Binary \\
\hline $\begin{array}{l}\text { Environmental } \\
\text { membership }\end{array}$ & $\begin{array}{l}\text { Member of environment organization (yes }=0 \\
\text { and } n o=1 \text { ) }\end{array}$ & Binary \\
\hline Guide & Hire a guide $($ yes $=0$ and no $=1)$ & Binary \\
\hline Travel group & $\begin{array}{l}\text { Nature of group }(0=\text { Alone, Family }=2, \\
\text { Friends }=3 \text {, Friends and Family } 4)\end{array}$ & Continuous \\
\hline Travel size & No of people in a travel group & Continuous \\
\hline Income & Income of respondent & Ordered \\
\hline
\end{tabular}

\section{Results and discussion}

\section{WTP by users}

Out of total users, $16 \%$ were willing to pay NRs. 5.05(US\$ 0.07) and less per HH per month,

\section{Factors affecting WTP by users}

The table 3 shows the results of multiple regressions on WTP by the users for their efforts towards sustainable management and conservation of the forest resources. The results 
of a multiple regression show that land holding and family size were significant $(\mathrm{p} \leq 0.01)$ with positive regression coefficient. That means the WTP increases with increase in land holding size and family size. The same result was obtained through focus group discussion. Similarly, the distance and residence were significant $(\mathrm{p} \leq 0.01)$ with negative regression coefficient. The negative regression coefficient of distance indicates that WTP decreases as the distance from the forest increases. Likewise, the users with old residences (with negative coefficients) were found to be more willing to pay as compared to the recently migrated ones. However, the positive coefficient in gender indicates that the females are more willing to pay as compared to the males (53 out of the 95 surveyed were male).

Table 3: Results of the multiple regression model on WTP for sustainable management and conservation from user's perspective

\begin{tabular}{lrrr}
\hline \multicolumn{1}{c}{ Variables } & Coefficient & Std. Error & Z-value \\
\hline Constant & 1.390 & .246 & 5.663 \\
Distance* & -0.00007 & .000 & -4.231 \\
Family size* & .209 & .039 & 5.293 \\
Gender** & .461 & .190 & 2.427 \\
Land holding* & .011 & .003 & 3.144 \\
Occupation*** & .086 & .048 & 1.769 \\
Residence* & -.666 & .219 & -3.048 \\
\hline
\end{tabular}

* significant at $10 \%$ level

** significant at $5 \%$ level

$* * *$ significant at $1 \%$ level

\section{Willingness to pay by tourists for ecosystem services}

The tourists visiting the BBZCF were divided into three groups 1) Nepali 2) tourists from SAARC countries except Nepal and, 3) tourists from other countries. The average WTP per tourist per visit on the basis of different zones (1,2 and 3) for recreational and aesthetic services were US\$ 52 , 96 and 104 respectively. The average number of tourists on the basis of different zones (1, 2 and 3) from the records (Fiscal Years: 2003/04 2008/09) of BBZCF Office were 8,237, 4,518 and 28,487 respectively. So, the projected average WTP on the basis of different zones (1,2 and 3) would be US\$ 425,194 , US\$ 432,870 and US\$ $2,948,405$ respectively per tourist per visit per year. Therefore, the total projected WTP by all tourists was found to be $\$ 3,806,468$ per year.

\section{Factors affecting WTP by tourists}

While doing the regression analysis of various independent factors on WTP for the recreational and aesthetic services, the tourists were divided into two groups viz. domestic and international.

The table 4 shows only the results of multiple regression of domestic tourists only. The income was significant $(\mathrm{p} \leq 0.05)$ with positive regression coefficient, suggesting that WTP increases with the increase in the level of income. The guide and member of environmental organization was not significant; however; the negative coefficient suggests that respondents who had hired a guide and were members of any environment organization were more willing to pay than those who had not hired a guide and were not members of any environmental organization. The negative sign of travel size indicates that higher the travel group, the lower the probability of WTP.

Table 4: Results of the multiple regression model of domestic tourists on WTP (NRs.) [1 US\$= NRs. 72.67]

\begin{tabular}{lrrr}
\hline \multicolumn{1}{c}{ Variables } & Coefficient & Std. Error & t-value \\
\hline Constant & 4352.483 & 2295.736 & 1.896 \\
Gender & -662.451 & 909.692 & -.728 \\
Age & 66.019 & 225.754 & .292 \\
Travel size & -29.986 & 80.408 & -.373 \\
Travel group & -517.514 & 420.109 & -1.232 \\
Education & 89.683 & 321.520 & .279 \\
Environmental & -994.054 & 799.573 & -1.243 \\
membership & & & \\
Income ** & 718.602 & 280.048 & 2.566 \\
Guide & -775.182 & 832.943 & -.931 \\
\hline
\end{tabular}

** significant at 5\% level

The table 5 indicates the results of multiple regression model of international tourists. In terms of individual significance of the explanatory variables, the education and income were significant $(\mathrm{p} \leq 0.01)$ with a positive regression coefficient, suggesting that higher the income and education, the higher the probability of selecting bigger bid amount. Similarly, the gender and travel group were also significant $(p \leq 0.01)$ with 
the positive sign, indicating that females were more WTP than males and the visitors who were with their family or with friends and family were more willing to pay as compared to solitary visitors. The negative regression coefficient on guide suggests that the tourists who had hired guide were more willing to pay than the tourists who had not.

Table 5: Results of the multiple regression model of international tourists on WTP (\$)

\begin{tabular}{lrrr}
\hline \multicolumn{1}{c}{ Variables } & Coefficient & Std. Error & Z-value \\
\hline Constant & 21.655 & 11.264 & 1.923 \\
Gender* & 18.073 & 5.796 & 3.118 \\
Age & 2.423 & 1.487 & 1.629 \\
Education* & 11.874 & 1.973 & 6.017 \\
Environmental & -18.373 & 7.721 & -2.380 \\
membership** & & & \\
Income * & 11.269 & 1.732 & 6.507 \\
Guide & -8.134 & 5.551 & -1.465 \\
Travel size & -.797 & .847 & -.941 \\
Travel group* & 4.388 & 1.612 & 2.722 \\
\hline * significant at 10\% level & & \\
** significant at 5\% level & & \\
\hline
\end{tabular}

\section{Discussion}

The total WTP for the sustainable management and conservation of BBZCF by users was calculated as US\$ 459 per HH per year. However, in a similar research conducted by Chand (2010) in Ghodhaghodi wetland of Far-western Nepal, the maximum WTP for sustainable use and management was US\$ 31,453 per year. Though the BBZCF constitutes the greater area in comparison to Ghodhaghodi wetland, the value of WTP calculated for BBZCF is low. The survey revealed that people from the BBZCF who had diversified livelihood options in addition to subsistence farming were also willing to contribute voluntarily although they had capacity to contribute higher amounts. One of the reasons for this may be due to the negative impacts of wildlife on crop damages and human casualties. Except in Gyaneswor CF, the WTP value calculated in three CFs was found to be lower than in BBZCF. In addition to the lower income of the households, another reason of low WTP by the user group members of the CFs may be due to their inadequate awareness and knowledge about various services of community forests. The higher value of WTP in BBZCF might be due to the fact that the users of the BBZCF were getting better benefits owing to high movement of tourists and diversified livelihoods options in the former one.

The study revealed that the local respondents were willing to pay for the sustainable use, management and conservation of the BBZCF. The result of multiple regression shows that WTP decreases as per the decreased proximity of user group HHs from the buffer zone forest. This indicates that the users who are living near the forests are more willing to pay as compared to the ones living far. This may be due to the higher level of benefits to the HHs living close to the forests because of tourist flow and other benefits. This shows that the buffer zone community forest user committee should emphasize to distribute the benefits among all users equitably. In terms of gender, women were more willing to pay as compared to men. This may be because women have to spend more time in domestic chores such as collecting grass, firewood, fodder, bedding materials etc. which they get from the BBZCF. In addition, they can be benefited from the management of BBZCF. So, the policy makers and other stakeholders should consider bringing the women in the frontline of the BZ management programme. Surprisingly, HHs with more members was more willing to pay. This may be due to the dependency of larger families over the forest was high in comparison to the HHs with smaller family size. Similarly, the people having larger farms were more willing to pay as they had relatively higher per capita income as compared to the users having smaller ones. The residents who were living in the same locality for a longer period had higher willingness to pay than the new migrants as the older residents were already receiving various services and benefits from the BBZCF.

The total projected WTP for the recreational and aesthetic services provided by BBZCF by all tourists was US\$3,806,468 per year. Rana (2004) estimated the opportunity cost of establishing the CNP. The net direct use value of the park was equal to US\$ 9.4 million annually. On the basis of the unit values of watershed function, carbon sequestration, and biodiversity from a study conducted by Verma (2000) in Himachal Pradesh (India), the total environmental value of the CNP was estimated to be US\$ 1.06 billion annually. 
Theincomelevel ofboth domestic and international visitors had a significant association with WTP as visitors with high income had higher WTP for recreational and aesthetic values. The visitors who were accompanied by the local guides were found to be willing to pay more than those without the local guides. As reported, the guided tourists had better orientation and exposure to various tourist attractions and destinations. In comparison to the domestic tourists, the international tourists had high income-level, higher education and better value to recreational services. Similarly, the tourists who were accompanied by their families and friends had higher level of WTP. The tourists who had higher WTP were based on their recreation during elephant riding, jungle walk, bird watching, staying in the machans (watching tower) and canoeing. Therefore, the protected area manager should try to maintain the quality of the recreational benefits and sustainable natural resource management. However, according to Baral et al. (2008), the most visitors were found to be willing to pay an entry fee considerably higher than the current fee of US\$ 27 in Annapurna conservation area. The mean and median WTP were US\$ 69 and US\$ 74 respectively. The larger visitors' groups, use of guides, and their satisfaction seemed to have most positive influences on their willingness to pay for higher entry fees.

\section{Conclusion}

This study shows that the users and the visitors of the BBZCF have shown their willingness to pay for recreational and aesthetic services as there are good conservation efforts within the area. The study has revealed that females were more willing to pay as compared to the males, which indicates that females can be benefited more from management of the BBZCF. So, the policy makers and other stakeholders should consider bringing females in the frontline of the $\mathrm{BZ}$ management program. The willingness to pay by tourists suggests that there is a possibility of generating extra income with the development of appropriate payment mechanism and equitable benefit sharing for better resource management, to enhance the quality of recreational benefits and for community welfare. Though there are different types of ecosystem services, this research only takes into account of recreational and aesthetic services. The study suggests that there is high potentiality to generate extra fund for financial sustainability in protected areas of Nepal.

\section{References}

BBZCF. 2007. Operational Plan, 2003-2007. Baghmara Buffer Zone Community Forest User Groups Baghmara, Bachhauli, Chitwan, Nepal.

Baral, N., Stern, M. J., and Bhattarai, R. 2008. Contingent valuation of ecotourism in Annapurna Conservation Area, Nepal: Implications for sustainable park finance and local development. Ecological Economics 66: $218-227$.

Bryman, A. 2006. Integrating quantitative and qualitative research: how is it done? Qualitative Research 6 (1): 97-113.

Chand, K. P. 2010. Economic Valuation of Wetland. A Case Study of Ghodaghodi Wetland. M.Sc. Thesis, Tribhuvan University, Kirtipur, Kathmandu, Nepal.

Collins, A. 1999. Tourism development and natural capital. Annals of Tourism Research 26 (1): 98-109.

Costanza, R., Agre, R. D., Groot, R. D., Farber, S., Grasso, M., Hannon, B., Limburg, K., Naeem, S., Neill, R. V., Paruelo, J., Raskin, R. G., Sutton, P. and Belt, M. 1997. The value of the world's ecosystem services and natural capital. Nature 387: 253-260.

Emerton, L., Bishop, J. and Thomas, L. 2006. Sustainable Financing of Protected Areas: A Global Review of Challenges and Options. The World conservation Union (IUCN), Gland, Switzerland and Cambridge, UK.

Engel, S., Pagiola, S. and Wunder, S. 2008. Designing payments for environmental services in theory and practice: An overview of the issues. Ecological Economics 65 (4): 663-674.

Gossling, S. 1999. Ecotourism: A means to safeguard biodiversity and ecosystem functions. Ecological Economics 29 (2): 303-320.

IIED. 2003. Valuing Forests: A Review of Methods and Applications in Developing Countries. International Institute for Environment and Development 
Environmental Economics Programme, 3 Endsleigh Street, London WCIH 0DD, UK.

IUCN. 2005. Benefits Beyond Boundaries. Proceedings of the 5th IUCN world parks congress. Durban, South Africa 8-17 September 2003. The World Conservation Union (IUCN), Gland, Switzerland and Cambridge, UK.

Johnson, R. B., Onwuegbuzie, A. J.and Turner, L. A. 2007. Toward a definition of mixed methods research. Journal of Mixed Methods Research 1 (2): 112-133.

Karna, P. K. 2008. Making payment for environmental services (PES) work: A case study of Shivapuri National Park, Nepal. In Shifting Paradigms in Protected Areas Management (eds) Bajracharya, S. B. and Dahal, N., NTNC, Kathmandu, Nepal, 171-185.

Khanal, Y., Upadhyaya, C. P. and Sharma, R. P. 2010. Economic valuation of water supply services from two community forests in Palpa district. Banko Janakari 20 (1): 24-29.

Kumar, P. 2005. Market for Ecosystem Services. International Institute for Sustainable Development (IISD), Winnipeg, Manitoba, Canada.

Loomis, J. 1996. Measuring the benefits of removing dams and restoring the Elwha River: results of a contingent valuation survey. Water Resources Research 32 (2):441-447

Maskey, N. A. 2008. Investing in Ecosystem Services: Opportunities and Challenges for Shivapuri National Park, Nepal Graduate Thesis. Lund University Master of Environmental Studies and Sustainability Science, Lund, Sweden.

McMurray, A. J., Pace, R. W. and Scott, D. 2004. Research: A Commonsense Approach. Thompson Social Science Press. ISBN: 0170122352, Melbourne, Australia.

Milder, J. C., Scherr, S. J. and Bracer, C. 2010. Trends and future potential of payment for ecosystem services to alleviate rural poverty in developing countries. Ecology and Society 15 (2): 4. [online] URL: http://www. ecologyandsociety.org/vol15/iss2/art4/
MEA. 2005. Ecosystem and Human Wellbeing: Synthesis, Island Press, Washington, DC, USA. Retrieved from http://www. maweb.org/documents/document.356.aspx. pdf, accessed on 18 October 2010.

Nepal Conservation Research and Training Center, 1997. Promoting Local Guardianship of Endangered Species and Wild life Habitat in Royal Chitwan National Park, Nepal. Final technical report submitted to Biodiversity Conservation Network, Kathmandu, Nepal.

Neto, F. 2003. A new approach to sustainable tourism development: Moving beyond environmental protection. Natural Resources Forum 27: 212-222.

Pagiola, S. and Platais, G. 2002. Payments for Environmental Services. Environment Strategy Notes No 3. The World Bank, Washington DC, USA.

Pant, P. 2003. Fuelwood Consumption Pattern in Lowland Nepal: A Case Study in Baghmara Buffer Zone Community Forest, Chitwan, Nepal. M.Sc. Thesis, Pokhara University, Pokhara, Nepal.

Pattanayak, S. K., Wunder, S. and Ferraro, P. G. 2010. Show me the money: Do payments supply environmental services in developing countries? Review of Environmental Economics and Policy 4 (2): 254-274.

Rana, A. S. 2004. The Opportunity Cost of Biodiversity Conservation in Nepal: A Case Study of Royal Chitwan National Park, M.Sc. Thesis, Kathmandu University, Nepal.

Rogerson, C. M. 2006. Pro-poor local economic development in South Africa: the role of propoor tourism. Local Environment 11: 37-60.

Scherl, L. M., Wilson, A., Wild, R., Blockhus, J., Franks, P., McNeely, J. and McShane, T. 2004. Can Protected Areas Contribute to Poverty Reduction? Opportunities and Limitations. IUCN, Gland, Switzerland and Cambridge, UK.

Singh, B. K. and Sharma, N. 2008. "An Analysis of Payment for Environmental Services from Biodiversity Perspective in Nepal" paper presented on Fifth Community Forestry National Workshop, Kathmandu, Nepal. 
Sommerville, M., Jones, J. P. G., Rahajaharison, M. and Milner-Gulland, E. J. 2010. The role of fairness and benefit distribution in community-based payment for environmental services interventions: A case study from Menabe, Madagascar. Ecological Economics 69: 1262-1271.

Tamrakar, A. 2002. Resource Management in Community forest: A Case Study from Baghmara Community Forest of Bachhauli VDC, Buffer Zone of Royal Chitwan National Park. M.Sc. Thesis, Pokhara University, Pokhara, Nepal.

Tashakkori, A. and Teddle, C. 2003. Handbook of Mixed Methods in Social and Behavioral Research. Thousand Oaks: Sage Publications, Inc. Thousand Oaks, California, USA.
Verma, M. 2000. Economic Valuation of Forests of Himalchal Pradesh. International Institute for Environmental Development (IIED), London, UK.

Warner, K. 2008. The concept and application of PES. In Designing Payment for Ecosystem Services (eds.) Oliver, J., Emerton, L. and Smith, M. Report from the East Asian Regional Workshop in Hanoi on April 2008, Gland, Switzerland, 8-11.

Wunder, S. 2005. Payments for Environmental Services: Some Nuts and Bolts. CIFOR Occasional Paper, No. 42, CIFOR, Bogor, Indonesia. 